\title{
The Influence of Leadership, Talent Management, Organizational Culture and Organizational Support on Employee Engagement
}

\author{
Jimmy Sadeli \\ Universitas Bina Nusantara, Jakarta
}

A R T I C L E I N F O
Keywords:
Talent management practices,
Employee engagement,
Transformational and transactional
Leadership behaviors,
Leadership-driven model on employee
engagement
engagement

\section{A B S T R A C T}

A leadership-driven model was hypothesized to examine the simultaneous influences of three dimensions of leadership behaviors (transformational, transactional, and interaction between transformational and transactional) on employee engagement, mediated by three intangible organizational factors: (1) talent management practices, (2) organizational culture, and (3) perceived organizational support (POS). Results of this research show that leadership behaviors (transformational and interaction between transformational and transactional) significantly influence mediating variables (talent management practices, organizational culture and POS), whereas transactional leadership must interact with transformational leadership behavior to influence mediating variables. Both talent management practices and organizational culture influence employee engagement, while POS indirectly influences employee engagement.
$\mathrm{T}$ he general objective of this research is to study strategic human resource management (SHRM) in the context of strategic management. The importance of leaders and the manner in which leaders lead and manage human resources strategically are now inevitable since the source of competitive advantage in the knowledge based economy has shifted to people (human capital / talent) (Pfeffer, 1995; Wielemaker \& Flint, 2005). Furthermore, Bartlett and Ghoshal
(2002) emphasize that human capital must be the starting point and ongoing foundation of successful strategy (p. 34). To gain the sustainable competitive advantage, it is critical for the leaders and organization to look beyond traditional human resources management.

Therearethreespecificleadership-drivenintangible variables (talent management, organizational culture and perceived organizational support - 
POS) that can potentially lead to better employee engagement, which subsequently results in better firm performance. The researcher seeks to examine the relationship between the influence of leadership behaviors (transformational, transactional, or the interaction or combination of the two behaviors) on employee engagement, mediated by the three aforementioned variables.

\section{Employee Engagement}

A talented workforce with dynamic capabilities alone does not suffice. Instead, employees have to be engaged to ensure a higher productivity at work (Lawler III, 2008; Cappelli, 2008a; Schiemann, 2009), thus allowing organizations to acquire competitive advantage (Macey, Schneider, Barbera, \& Young, 2009).

Despite the frequent use of employee engagement strategies in organizations, researches on the effective development thereof is surprisinglylacking (Macey \& Scheneider, 2008 and Saks, 2006). Thus, there exists a gap between researchers' findings on the importance of employee engagement and the lack of research on the creation of employee engagement methods (Shuck, 2010).

\section{Talent Management}

Talent management, a frequent topic in management levels today, is a comprehensive framework for managing talented employees and enhancing their contribution to company performance e.g. Bartlett \& Ghoshal, 2002; Berger \& Berger, 2004; Cappelli, 2008a; Collings \& Mellahi, 2009; Lacy, Arnott, \& Lowitt, 2009; Lawler III, 2008; Macey et al., 2009; Pfeffer, 2001).

It is nonetheless essential to note that despite its importance to organizational success, talent management is but a recent and evolving concept (Lewis and Heckman, 2006), with ambiguous definitions and a dearth of empirical research (Collings and Mellahi, 2009; Cappelli, 2008a). There are even fewer researches that explicitly relate talent management and employee engagement. Examples include an article written by Hughes and Rog (2008) and a model explaining the relationship between talent management, employee engagement and firm performance offered by Schiemann (2009). Ashton \& Morton (2005) and Barlett \& Ghoshal (2002) also emphasize the importance of employee engagement element in managing talents in an organization.

In this study, the researcher proposes to view talent management practices from a social exchange theory perspective in their relationship with organizational initiatives and employee engagement. From a social exchange theory perspective, employee engagement occurs when an organization treats employees very well and the employees respond by focusing and contributing more to their job and to the organization (Eisenberger et al., 1986; Eisenberger, et al., 1990; Saks, 2006).

\section{Organizational Culture, Perceived Organizational Support, Organizational Leaders and Their Relationship with Employee Engagement}

Employee engagement does not depend on talent management practices alone; there are other organizational factors or context that may influence employee engagement: organizational culture (Macey et al., 2009; Wildermuth \& Pauken, 2008a) and perceived organizational supports (Rich et al., 2010; Saks, 2006). Studies have also demonstrated that important organizational activities are influenced by organizational leaders, and such activities include selecting and developing the next generation of leaders (i.e. talent management), sustaining an effective organizational culture; and developing organizational structures, processes and controls (i.e. perceived organizational support) (Hickman, 1998; House \& Aditya, 1997; Hunt, 1991; Ireland \& Hitt, 1999; Selznick, 1984; Zaccarro, 1996a all in Boal \& Hooijberg, 2001, p. 516; Saks, 2006; Wildermuth \& Pauken, 2008a; Yukl, 2009).

\section{Research Questions}


The main research question is: How is employee engagement affected by leadership behavior, and what are these effects? It is divided into 12 topics :

1. How significant are the influences of talent management practices on employee engagement?

2. How significant are the influences of perceived organizational culture on employee engagement?

3. How significant are the influences of perceived organizational support (POS) on employee engagement?

4. How significant are the influences of transformational leadership on talent management practices?

5. How significant are the influences of transformational leadership on perceived organizational culture?

6. How significant are the influences of transformational leadership on perceived organizational support (POS)?

7. How significant are the influences of transactional leadership on talent management practices?

8. How significant are the influences of transactional leadership on perceived organizational culture?

9. How significant are the influences of transactional leadership on perceived organizational support (POS)?

10. How significant are the influences of interaction between transformational and transactional leadership behaviors on talent management practices?

11. How significant are the influences of interaction between transformational and transactional leadership behaviors on perceived organizational culture?

12. How significant are the influences of interaction between transformational and transactional leadership behaviors on perceived organizational support (POS)?

\section{Research Contributions}

This research is expected to contribute in enriching and enhancing the existing knowledge of strategic human resource management (SHRM) and strategic management as well as talent management, employee engagement and organizational behavior disciplines. This research examines the influence of leadership and organizational factors (talent management practices, organizational culture and POS) on employee engagement in a single research model. Having all main research variables in a single research model will provide insights on the relative and comparative influence of those variables in predicting the outcome variable (employee engagement). Hence, specific research contribution is to empirically demonstrate the influence of a leadership-driven talent management, perceived organizational culture and POS simultaneously in generating higher employee engagement level which supposedly leads to better firm performance.

Results of the research are expected to provide suggestions for Indonesian companies, top executives and managers on the most effective type of leadership behavior for the purpose of attaining and sustaining organizational success.

\section{THEORETICAL FOUNDATIONS}

This research on strategic human resource management (SHRM) in the context of strategic management is based on previous research on the strategic role of human resources in building sustainable competitive advantage in firms.

Barlett \& Ghoshal (2002) and Pfeffer (1995, p. 56) concur that, in a knowledge-based economy, the key source and differentiating factor for a firm's sustainable competitive advantage is people. Based on meta-analyses, a firm's employee engagement level can be a surrogate variable of its organizational performance (Harter, et al. 2002). It therefore follows that HRM in firms today should be involved in strategy formulation and be a core organizational competency (Wielemaker and Flint, 2005). 
This research aims to link SHRM and strategic management by examining relationships between types of leadership behavior (transformational, transactional and interaction between transformational and transactional leadership behaviors) with employee engagement as mediated by three organizational factors: talent management practices, perceived organizational culture and perceived organizational support (POS).

\section{Social Exchange Theory as an Integrating Theory}

In this research, social exchange theory (SET) (Blau, 1964) is the integrating framework to explain relationships between the three main research variables: leadership, perceived organizational support (POS) and employee engagement. In previous research, SET has been used as a framework for understanding employee engagement, POS, and leadership (Saks, 2006; Wayne et al., 1997; Wayne et al., 2002).

SET explains reciprocal behavior between individuals, between followers and leaders, and between employees and organizations (Aselage \& Eisenberger, 2003; Cole et al., 2002; Dienesch \& Liden, 1986; Gouldner, 1960; Organ, 1988; Saks, 2006; Wayne et al., 1997; Wayne et al., 2002). An example in working relationship is where an employer or organization provides compensation and benefits in exchange for employees' contributions. In such relationship, an economic exchange would include the provision of remuneration and benefits to employees and a social exchange would be represented by the employees' passion in contributing to the job or organization (Blau ,1964)

The basic principle of SET is reciprocal interdependence between parties (Saks, 2006). When an organization treats employees extraordinary well, (e.g. POS), then employees respond in a positive manner and go beyond their call of duties. They are more engaged in their jobs, are more productive, and engaged in extra positive behavior to co-workers and the company. On the other hand, in an organization that treats employees strictly in accordance with company rules, employees respond only within the premise of their contract or job description, i.e., take whatever exchange the organization offers. This places the organization over the employees, where the organization is the initiator of the exchange process.

An organization's leader is the one with the decisive power to initiate the exchange process. Leadership behavior is reflected in the leader's choice of exchange (i.e., economic or social) and its execution. Leaders tend to invest more time with subordinates with better relationship qualities (Wayne et al., 1997). Reciprocally, employees tend to invest more time and energy in their jobs to show gratitude to leaders (Dienesch \& Liden, 1986).

Leaders can influence on organizational culture (Schein, 1990) and POS (Wayne, Shore, Bommer \& Tetrick, 2002), activities and mechanisms such as talent management practices (Hemphill \& Coons, 1957 in Yukl, 2006; Rauch \& Behling, 1984 in Yukl, 2006; Katz \& Kahn, 1978 in Yukl, 2006; Schiemann, 2009). Leaders may direct some espoused values and behaviors such as cultural norms to be engendered in the organization's culture. The organization recognizes positive employee behaviors as guided by cultural norms; this creates certain social exchange relationships (Cole et al., 2002).

\section{Employee Engagement Theory}

Employee engagement, a topic recently popular among human resources practitioners, consulting firms and academicians, has definitions and constructs that frequently overlap (Saks, 2006; 2008). In the business sense, employee engagement is often explained in term of how much energy and passion employees exert in their tasks (e.g. Buckingham \& Coffman, 2005; Cook, 2008; Colan, 2009; Croston, 2008). When 
Definitions of Employee Engagement, Employee Satisfaction, Organizational Commitment, Job Involvement and Organizational Citizenship Behavior

\begin{tabular}{|c|c|c|c|c|c|}
\hline & $\begin{array}{l}\text { Employee } \\
\text { Engagement }\end{array}$ & $\begin{array}{l}\text { Employee } \\
\text { Satisfaction }\end{array}$ & $\begin{array}{l}\text { Organizational } \\
\text { Commitment }\end{array}$ & $\begin{array}{l}\text { Job } \\
\text { Involvement }\end{array}$ & $\begin{array}{l}\text { Organizational } \\
\text { Citizenship } \\
\text { Behavior }\end{array}$ \\
\hline Definition & $\begin{array}{l}\text { "Employees } \\
\text { who believe in } \\
\text { the company's } \\
\text { goals and } \\
\text { objectives } \\
\text { are proud to } \\
\text { work there } \\
\text { and prepared } \\
\text { to put in the } \\
\text { extra effort } \\
\text { in working } \\
\text { toward those } \\
\text { goals and will } \\
\text { stay with the } \\
\text { organization." }\end{array}$ & $\begin{array}{l}\text { "General } \\
\text { cognitive } \\
\text { evaluation of } \\
\text { an employee's } \\
\text { overall work } \\
\text { experience } \\
\text { and fulfillment } \\
\text { of basic } \\
\text { employee } \\
\text { needs." }\end{array}$ & $\begin{array}{l}\text { "Attitudes and } \\
\text { attachment } \\
\text { towards their } \\
\text { organization." }\end{array}$ & $\begin{array}{l}\text { "Job } \\
\text { involvement } \\
\text { is the result } \\
\text { of a cognitive } \\
\text { judgment } \\
\text { about the } \\
\text { need to satisfy } \\
\text { requirements } \\
\text { of the job and } \\
\text { is tied to one's } \\
\text { self-image." }\end{array}$ & $\begin{array}{l}\text { Employees } \\
\text { behave } \\
\text { voluntarily, } \\
\text { informally and } \\
\text { pro-socially, } \\
\text { are not directly } \\
\text { rewarded } \\
\text { by a formal } \\
\text { incentive } \\
\text { scheme, and } \\
\text { will support } \\
\text { functionality } \\
\text { of co- } \\
\text { workers and } \\
\text { organization. }\end{array}$ \\
\hline Source & $\begin{array}{l}\text { Towers Perrin, } \\
2005, \text { p.2 }\end{array}$ & $\begin{array}{l}\text { Kahn }(1990 \text {, in } \\
\text { Heger, 2007, p. } \\
122)\end{array}$ & Saks, 2006 & $\begin{array}{l}\text { May (2004 in } \\
\text { Saks 2006, p. } \\
602)\end{array}$ & Saks, 2006 \\
\hline
\end{tabular}

employees spend more energy and passion in their careers, they are said to be engaged.

A high level of employee engagement in an organization leads to a high aggregate productivity and organizational performance (e.g. Cook, 2008; Corace, 2007; Colan, 2009; Fleming \& Asplund, 2007; Konrad, 2006; Macey et al., 2009). It has been observed that employee engagement directly affects firm performance (a meta-analysis by Harter, Schmidt \& Hayes, 2002). This metaanalysis, Schiemann (2009) and study results from top consulting firms (e.g. Hay Group, Towers Perrin \& Watson Wyatt) are likely suggesting that the level employee engagement is a surrogate variable of firm performance indicator (e.g. Macey et al., 2009; Ormanidhi \& Stringa, 2008).

Two types of employee engagement are: job and organizational engagement (Saks, 2006). Job engagement refers to engagement to a job; organizational engagement is directed to an organization. Thus, job engagement explains an employee's focus, passion, energy and time to complete a job and, consequently, being more productive compared to disengaged employees. Organizational engagement includes employee pride or excitement in being part of an organization.

The table below demonstrates the comparison between employee engagements and employee satisfaction, organizational commitment, job involvement and organizational citizenship behavior.

\section{Talent Management Practices}

Developing talents (employees) is one of the main responsibilities that should be pursued by an organization and its leaders to continuously upgrade employees' knowledge and skills (e.g. Berger \& Berger, 2004; Cappelli, 2008a; Lawler III, 2008). In talent management, the first factor and most important foundation for employees' development is having a competencies model and implementing it (Berger \& Berger, 2004). A well defined competencies model that is derived 
from organizational strategic needs should be able to elaborate specific competencies required for each position and incumbent (employee) who is accountable to carry out the tasks. Each employee is assessed against the required competencies proficiency levels. The competencies assessment results will be used to develop all employees so that employees will be able to execute tasks as expected and perform well, in some cases exceeding expectations. It is not unusual for some organizations to invest more in high potential employees than ordinary employees due to expectations of higher positive contributions to the organization (Buckingham \& Coffman, 1999; Lawler III, 2008).

The second factor in development is a well-defined performance management system (Berger \& Berger, 2004). A performance management system is needed by all organizations to ensure that all employees focus on an organization's agreed strategic direction. Armstrong (2004, p. 1) defines performance management as:

"a strategic and integrated process that delivers sustained success to organizations by improving the performance of the people who work in them and by developing the capabilities of individual contributors and teams"

The word performance itself refers both to results and behaviors (Braumbrach, 1988 in Armstrong, 2004). When an organization implements a welldefined performance management system, every job position and all job holders will be given a performance scorecard which contains measures of success (key performance indicators or KPI). The performance scorecard measures are derived and cascaded down from the organization's vision, mission, values and strategic objectives. The performance scorecards are defined in quantitative terms so that the objectivity of the performance evaluation will be optimized (Kaplan \& Norton, 1996).
A performance management system actually complements competency. This statement is derived from Spencer and Spencer's (1993, p. 9) definition of competency: "an underlying characteristic of an individual that is casually related to criterion-reference effectivity and/or superior performance in a job or a situation." In other words, competency leads to performance. Development requires a competency model as the basis and needs a performance management system to ensure its effectiveness (the objective of talent development is their performance).

The issue of retaining talented employees (high performance talent) in an organization has attracted major attention from many organizations' leaders (Lawler III, 2008). There have been a number of studies to estimate the costs involved in talented employees turnover, and the general conclusion of the studies is that not only are there significant costs involved but also difficulties in finding and attracting potential talented employees from the market (Lawler III, 2008, Michaels et al. 2001). According to Lawler III (2008), there are two steps in retaining talented employees: to identify them and to reward them at a high level. A reward scheme must be tied in with an effective performance management system.

Effective retention practices may lead to more talented people staying in the organization, leading to a better condition for the organization in terms of effective succession management system (Berger \& Berger, 2004).

\section{Organizational/Corporate Culture Theory}

Perceived organizational culture is also proposed as another antecedent of employee engagement. In the modern conceptualization of organizational or corporate culture, Schein (1996, p. 236), explains that culture is "sets of shared, taken for granted, implicit assumptions that a group holds." Like Schein, other theorists such as Weber (1930 in Keesing, 1974), Mead (1934 in Keesing, 1974) and Radcliffe-Brown (1953 in Keesing, 1974) described 
culture as a system of behavioral patterns that can be socially spread among members of a community (Keesing, 1974).

Among many definitions of organizational culture, Schein's (1990) definition remains the most basic and comprehensive:

"the basic set of assumptions that are invented, discovered or developed by a given group or leader as it learns to cope with its problems of external adaptation and internal integration which have worked well enough to be considered valid, and is then taught to new members as the correct way to perceive, think, and feel in relation to working to solve organizational problems" (Schein, 1990, p. 9)

Corporate culture will serve as the basis for and integrator of all management systems, procedures, practices and behaviors. With the culture as a unifying principle, it becomes easier for an organization to obtain many benefits such as better teamwork, faster decision making, and minimalization of management conflicts among members of the organization. Barney (1986) and Cameron \& Quinn (2006) show that culture is a major factor in the sustainability of organizational success and, ipso facto, culture is even more important than competitive advantage. In their study, they have noticed that there are five companies in the US that have consistently been ranked as the the top five performers over the past two decades - Southwest Airlines, Wal-Mart, Tyson Foods, Circuit City and Plenum Publishing (Compustat Data Services in Cameron \& Quinn, 2006) - and all have something in common: they do not have distinctive competitive advantages compared to other competitors in their respective industries, yet"the most powerful factor they all highlight as a key ingredient in their success, is their organizational culture", and that has kept them going for decades (Cameron \& Quinn, 2006, p. 4).
Schein (1990) suggests that a leader or group of leaders create and develop a basic set of assumptions that can be shared and implemented in an organization to enable the organization to survive against internal and external issues, problems or even threats. If those assumptions are accepted by the organization's members and are later utilized as a source of reference in facing organizational issues, they will be considered as valid assumptions and subsequently as living values or principles that must be taught and transmitted to other organization members.

Organizational culture and its relation to organizational effectiveness has been studied comprehensively by Denison (1990) and other researchers such as Fey (2003), Haaland and Goelzer (in Denison, Haaland \& Goelzer, 2003). Organizational culture is unique for each organization (Appelbaum et al., 2004), and an employee may be engaged when his or her personal values align with organizational values (Macey et al., 2009; Wildermuth \& Pauken, 2008a). As previously indicated, employee engagement will yield increased organizational effectiveness and eventually lead to sustained organizational success.

\section{Perceived Organizational Support (POS) Theory} In addition to organizational culture, POS is a contextual factor which can affect the level of employee engagement (Byrne \& Hochwarter (2008), Harter et al. (2002), Saks (2006)).

POS is the employees' perception of the extent to which the organization values their contributions and cares about their well being (Eisenberger, Fasolo, \& Davis-LaMastro, 1991; Eisenberger, Huntington, Hutchison, \& Sowa, 1986; Shore $\&$ Tetrick, 1991). The basic premise for these relationships is social exchange theory (SET) (Cole et al., 2002; Shore \& Tetrick, 1991).

This theory suggests an interaction is a form of exchange (Homans, 1961 in Blau, 1964). According 
to Blau (1964), both parties are attracted to each other if they expect the interaction to be in some way mutually rewarding. It is important that both parties continue to exchange rewards with each other in order to sustain mutual attraction and, hence, to prolong interaction. In the context of the employer-employee relationship, the exchange will continue if both parties experience mutual benefits: the employer gets performance and, in return, the employees get financial and non financial rewards.

In addition, SET suggests that differences in interactions among exchange parties may arise because one party may be more attracted to some specific parties, which creates a stronger bond between them (Blau, 1964). The notion that each interaction may be different may lay a foundation for differentiated treatment among employees by the employer. In other words, an employer may provide supports extending beyond those specified in the general company policy for employees with higher potential and contribution, with the hope of reciprocation in the form of better engagement and performance on the employees' part.

Wayne et al. (1997) and Wat \& Shaffer (2005) suggest that leadership may influence POS as employees perceive organizational support as an equivalent to leaders' support, and they feel obliged to repay the leader as well as the organization. Levinson (1965, in Wayne et al. 1997) called this support a personification of the employer or organization where leaders' or supervisors' treatments to other organizational members will be perceived as organizational action. Correspondingly, in this proposed research model, leadership is hypothesized as an antecedent of POS.

\section{Strategic Leadership and Leadership Theories}

The universal concept of leadership has existed since the beginning of civilization. In the development of leadership theories over the last 20 years, strategic leadership theory has been revitalized to face the dynamic and uncertain environment. A new breed of leaders with excellent strategic leadership capabilities is needed to enable firms to beat the competition (Boal \& Hooijberg, 2001; Grant, 1999; Hitt, Haynes, \& Serpa, 2010; Yukl, 2009).

Despite the many different definitions of leadership emphasizing on different aspects thereof, Yukl (2002) suggests that the essence of effective leadership lies in a leader's ability to influence people "to carry out requests, support proposals and implement decisions."

\section{Theory of Transactional and Transformational Leadership}

The most recent evolutionary stage of leadership concerns transactional and transformational leadership theories. A leader can possibly be both transactional and transformational at the same time.

\section{Theory of Transactional Leadership}

Transactional leader promises some kind of rewards for services rendered by others. According to Yukl (2002), in transactional leaderships there is an exchange process between leaders and followers where followers comply with leaders' requests. However, the exchange will not create followers' commitment and passion. The exchange between promises and services rendered can be considered as an economic exchange or negotiated transaction (Graen, 1976 in Archbold, 2004). It can be linked to exchange theory where basically the principle is a reciprocal interdependence between persons, or persons with organizations (Saks, 2006).

Bass (1985) explains that there are three dimensions of transactional leadership: (1) contingent reinforcement, where followers receive rewards or punishment based on their performance, (2) active management by exception, where leaders implement regulations to prevent employees from making or repeating mistakes, and (3) passive 
management by exception, where leaders only intervene when something goes awry.

A transactional leader is the type of leader who fits in stable, predictable environments, works in existing systems or cultures; practises risk avoidance and strictness in terms of time and efficiency measures, and emphazises process over substance (Bass, 1985). In their metaanalysis, contrary to what is traditionally held, Lowe et al. (1996) show that transformational leadership is more frequently found in public sector organizations compared to private ones. The other findings by Lowe et al. (1996) are that contigency rewards are found to have impacts on organizational effectiveness; on the contrary, management-by-exception is found to have no impact on effectiveness.

\section{Transformational Leadership}

Bass (1985, p. 220) suggests that transformational leadership is an expansion of transactional leadership.

Transformational leadership is a nearly ideal type of leadership where followers always look up to leaders to seek inspiration, direction and support. Transformational leaders develop followers, instill high expectations and provide confidence to achieve greater performance. Tentative guidelines for transformational leaders to be effective in inspring and motivating followers are as follows (Yukl, 2002, p.263): (1) articulate a clear and appealing vision, (2) explain how the vision can be attained, (3) act confidently and optimistically, (4) express confidence in followers, (5) use dramatic, symbolic actions to emphasize key values, (6) lead by example, and (7) empower people to achieve the vision.

Transactional leadership has been traditionally viewed as unconstructive compared to transformational leadership. However, transformational leadership may only be more effective in "an unstable environment, an organic structure (rather than a mechanistic bureaucracy), an entrepreneurial culture, and dominance of boundary-spanning units over the technical core." (Yukl, 2002). However, a transformational leader may be ineffective in executing his tasks in the absence of transactional leadership (Lowe, Kroeck, \& Sivasubramaniam, 1996). In other words, an effective leadership style needs both transformational and transactional elements to be practiced simultaneously.

Combination of Transformational \& Transactional Leadership Behaviors and Interaction Effects of Two Leadership Behaviors

Burns (1978) suggests that transactional and transformational leadership behaviors are mutually exclusive, which means a leader can only either be transactional or transformational. Bass (1985) argues in fact that transformational leadership is an expansion of transactional leadership. The expansion is mainly of the effect on followers' "efforts, satisfaction and effectiveness" (Bass, 1990b, p. 53). Kuhnert and Lewis (1987) argue that Burns (1978) and Bass (1985) "identified leaders by their actions and the impact those have on others", however Burns and Bass did not explain the "framework for understanding the motivational states or personality differences that give rise to these two types of leadership" (p. 648). Further, Kuhnert and Lewis (1987) show that Bass (1985) identified "personality variables believed to distinguish transformational from transactional leaders, but Bass failed to explain how particular traits cohere to produce different types of leaders" (p. 650). Using constructive/ developmental personality theory as a framework for distinguishing leadership behavior, Kuhnert and Lewis (1987) show that "people vary in the ways they construct or organize experiences about themselves and their social and interpersonal environment and from this perspective that the organizational and perceptual structures of transactional leaders are quite distinct from those of transformational leaders" (p.650). 
Yukl (2002) suggests a combination of transformational and transactional leadership behavior can create an effective leader. Bass (1985) also suggests that transformational and transactional leadership paradigms be viewed as complementary to each other. Hence, an effective leader practices both transformational and transactional styles simultaneously. According to Bass, Avolio, \& Goldham, (1987 in Lowe et al., 1996, p. 387), "transformational leadership is complementary to the transactional style and likely to to be ineffective in the total absence of a transactional leadership style between leader and subordinate." Bass (1990b) mentions famous names such as Abraham Lincoln, Franklin Delano Roosevelt and John F. Kennedy who were considered great transformational leaders but also practiced a transactional style of leadership.

Bass (1985) and Yukl (2002) do not clearly specify in what particular situation a combination of transformational and transactional leadership behaviors will make an effective leader. Yukl (2002) asserts that a combination of transformational and transactional leadership behaviors should be viewed from the underlying influence processes of the two behaviors. Effective leaders are expected to be aware of distinctively employing the type of influence processes relevant to the context and facilitating conditions to have the most effective impacts on followers.

\section{Leadership and Social Exchange Theory}

Interactions between superiors-subordinates can be viewed from a social exchange perspective. Social exchange is frequently employed by researchers as a basis to explain or understand relationship that build between superiors and their subordinates (Keller \& Dansereau, 1995). The superiors provide support and other benefits to subordinates and subordinates are grateful and indebted to their leaders, and reciprocate with positive and productive behaviors (Hollander, 1978; Homan, 1961 all in Keller \& Dansereau, 1995). Blau (1964) suggests that a social exchange relationship between superiors and their subordinates is based on trust, hence when superiors give benefits to subordinates the feeling of gratitude and personal obligation of subordinates will develop. The subordinates will then reciprocate and this may lead to higher engagement with both their jobs and organizations (e.g. Rich et al., 2010; Saks, 2006).

The exchange relationship between superiorssubordinates has been studied by researchers under the term of leader-member-exchange (LMX) (e.g. Keller \& Dansereau, 1995; Sparrowe \& Liden, 1997; Wayne, Liden \& Sparrowe, 1994). This type of relationship is specifically labeled a dyadic relationship between superiors and subordinates. The key premise of LMX is: leaders develop different types of exchange relationships with different subordinates: high quality and low quality LMX (Dienesch \& Linden, 1986 in Keller \& Dansereau, 1995. Exchanges in high-quality LMXs (usually referred as "in-group") are characterized by mutual trust and support, meanwhile lowquality LMXs ("out-group") are normally based on contractual agreements.

\section{Integrating all Theories and Frameworks Employed in This Study}

Following is a pictorial summary of all theories and frameworks used for this particular study. The umbrella for all theories consists of relevant theories developed by strategic management researchers. As mentioned previously, this study examines how leaders with their leadership behaviors may influence organizational success through talented and engaged people as well as ensure that intangible elements (organizational culture and POS) are developed and implemented well. The success of an organization in outperforming competitors is one of the key issues in the strategic management field.

In the current knowledge-based economy, human resources are now the key to beating the competition; therefore, traditional Human 
Resources Management (HRM) has to be lifted up to a strategic level (SHRM) where all initiatives and programs in HRM must be linked and aligned with the strategic direction of an organization. To ensure that HRM is strategic, the personnel of the HR function need to be involved in strategy formulation processes, and HR must be a core competency in and of the organization (Wielemaker \& Flint, 2005).

Social exchange theory (SET) is employed as an integrating theory for the relevant theories used to deeply explain research variables: leadership, POS and employee engagement (Saks, 2006; Wayne et al., 1997; Wayne et al., 2002). SET has been employed to explain reciprocal behavior between persons, persons with leaders, or persons and organizations (Aselage \& Eisenberger, 2003; Cole et al., 2002; Dienesch \& Liden, 1986; Gouldner, 1960; Organ, 1988; Saks, 2006; Wayne et al., 1997; Wayne et al., 2002).

\section{Proposed Conceptual Model and Hypotheses}

Saks (2006) suggests two types of dimensions to measure employee engagement: job engagement and organizational engagement. There have not been many models of or much research on employee engagement and Saks's (2006) argument in the measurement of employee engagement is based on two streams of previous research and social exchange theory.

The basic logic for the proposed model is the emphasis on the strategic importance of the leadership behavior of a leader in determining the success of the organization through talented and engaged human capital. In measuring organizational success, the indicator of success in outperforming competitors is not always a financial indicator (Macey et al., 2009; Ormanidhi \& Stringa, 2008; Peteraf \& Barney; 2003; Pfeffer, 1995).

Further assessment of this proposed model can be found in other studies conducted by researchers concluding that leaders need mediating variables to influence employees in regard to their jobs and organizational engagement (Harter et al., 2002; Heger, 2007; Kahn, 1990; Luthans \& Peterson, 2002; May et al., 2004; Rich, 2010; Saks, 2006; Schaufeli \& Bakker, 2004; Schiemann, 2009).

The proposed conceptual model is as follows:

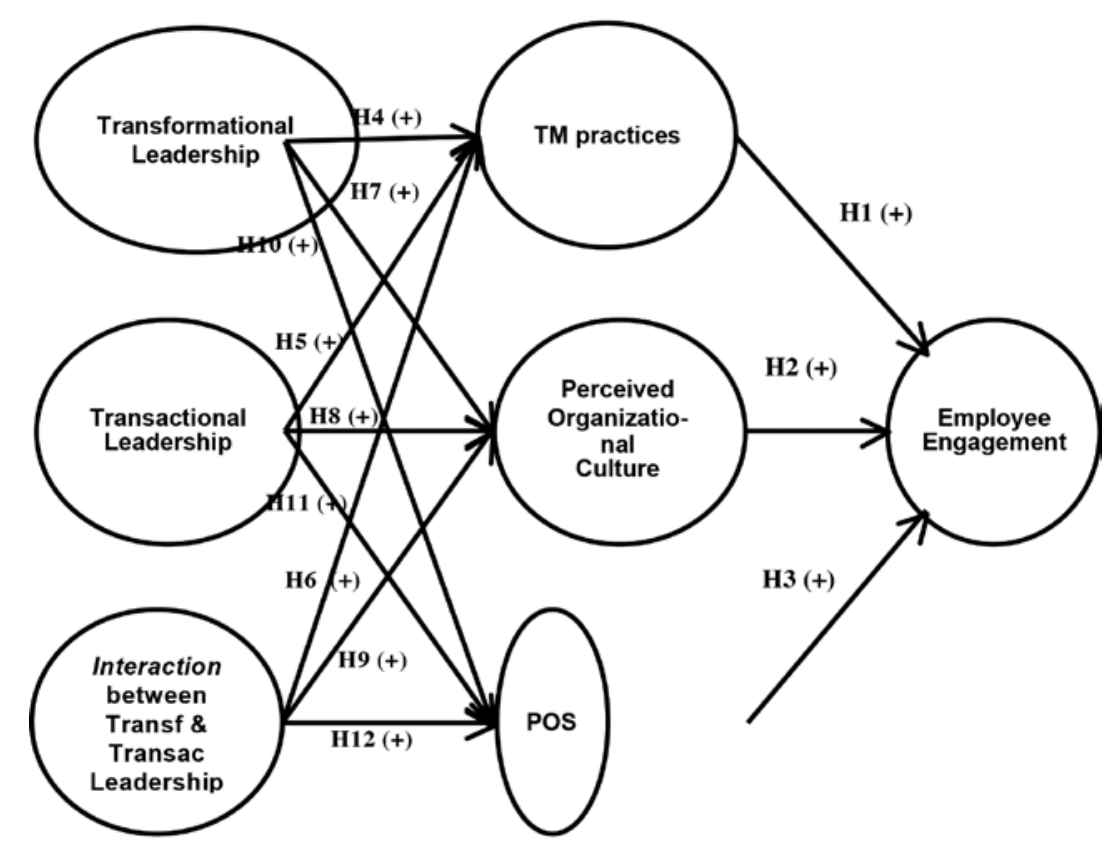




\section{METHODS}

\section{Background and LM-FEUI Approach (Methodology) on HRE 2009 Study}

Empirical studies on talent management and employee engagement are scarce since talent management and employee engagement can be considered as new fields in human resources and organizational behavior. It is even harder to find related studies on Indonesian companies. However, these two areas of human resources management are now acknowledged by many company leaders, researchers, and practitioners as vital to organizational success and survival in this era of knowledge-based economies. They agree that human capital is now the key to outperform competitors.

LM-FEUI and non-profit organization Human Resources Indonesia (HRI) had already conducted two studies on some aspects of human resources prior to 2009, aptly called Human Resources Excellence (HRE) 2007 and 2008. These previous studies mainly focused on traditional human resourcesfunctions, e.g. Recruitment, Performance Appraisal, Training and Development. After considering a few aspects and acknowledging that there was a dearth of empirical studies on talent management and employee engagement, HRE 2009 was designed mainly around these two strategic and yet relatively new aspects of human resources management, both in the theoretical and practical sense.

\section{Human Resources Excellence 2009 Survey Respondent Profiles}

HRE focuses on key and important human resources areas. The HRE 2009 study was planned and conducted carefully to ensure data accuracy. Compared to the previous HRE studies, HRE 2009 was seen as more successful in terms of the participants'number, reputation, and the size of the companies they work for.

The respondents of this study were employees of the participating companies classified as top management (10\%), middle management (30\%) and low management (60\%) employees. The closeended questionnaire with a six-point Likert scale was designed in such a way that the generated responses from the survey sample represented the population of the study. The survey did not easily attract companies to participate despite vigorous advertising in SWA. After the tireless efforts of the involved staff, 26 companies signed up to confirm their participation in the study. Most of the 26 participating companies had more than 250 employees.

Eight of the companies are public listed: PT Adira Dinamika Multi Finance; PT Bank OCBC NISP; PT SMART, Tbk.; PT Indosat, Tbk.; PT HM Sampoerna, Tbk.; PT Mandom Indonesia, Tbk.; PT Indocement Tunggal perkasa, Tbk.; and PT Semen Gresik (Persero), Tbk. Ten of the participating companies are state-owned enterprises (SOE) while ten are private companies.

There were 756 respondents from the 26 participating companies who returned the questionnaires. The high questionnaire return rate of $96.9 \%$, was attributed to the persistence of the survey coordinator of LM-FEUI and the cooperation of the contact persons assigned by each of the participating companies. The data collected in the survey also included the respondents' demographic data such as job position, years of service, age, etc. These data would prove useful at the later stage of statistical analysis.

\section{Respondents (Profile) General Description}

This research is conducted by distributing 780 sets of questionnaire to 26 participating organizations in Indonesia. From the total number of distributed questionnaires, 756 (96.9\%) of completed sets were returned and 728 (96.3\%) were considered valid to be analyzed further as a unit of analysis. The number of samples in the range of 100 200 is an appropriate number, especially from the perspective of overall fit measures that are fundamental: likelihood-ratio chi-square statistic 
Table 1. HRE 2009 Participating Companies

\begin{tabular}{|c|c|c|c|}
\hline No: & Company Name & Type of Industry & Type of Ownership \\
\hline 1 & PT SMART, Tbk. & Plantation & Public listed \\
\hline 2 & PT TNT Indonesia & Transportation \& Logistics & Private \\
\hline 3 & PT Wika Realty & Property Developer & $\begin{array}{l}\text { State Owned } \\
\text { Enterprise (SOE) }\end{array}$ \\
\hline 4 & PT Johnson Home Hygiene Products & Manufacturing - Consumer Products & Private \\
\hline 5 & PT Indocement Tunggal Prakarsa, Tbk. & Manufacturing - Cement & Public listed \\
\hline 6 & PT Adira Dinamika Multi Finance, Tbk & Financial Institution & Public listed \\
\hline 7 & PT Asuransi Jiwa Recapital & Insurance & Private \\
\hline 8 & PT HM Sampoerna, Tbk. & Manufacturing - Cigarettes & Public listed \\
\hline 9 & PT. Amoco Mitsui PTA Indonesia & Manufacturing - Chemical & Private \\
\hline 10 & PT Aetra Air Jakarta, Tbk & Clean Water Supplier & Private \\
\hline 11 & PT Indosat, Tbk & Communication & Public listed \\
\hline 12 & PT Garuda Food & Manufacturing - Food & Private \\
\hline 13 & PT Oracle Indonesia & Information Technology & Private \\
\hline 14 & PT SOHO Pharmaceutical & Manufacturing - Pharmacy & Private \\
\hline 15 & PT Bank OCBC NISP, Tbk. & Banking & Public listed \\
\hline 16 & PT Mandom Indonesia, Tbk. & Manufacturing - Consumer Products & Public listed \\
\hline 17 & PT Semen Gresik (Persero), Tbk. & Manufacturing - Cement & Public listed \\
\hline 18 & PT Angkasa Citra Sarana Catering Service & Catering & $\mathrm{SOE}$ \\
\hline 19 & Perum Pegadaian & Financial Institution & $\mathrm{SOE}$ \\
\hline 20 & PT Garuda Indonesia & Airline & $\mathrm{SOE}$ \\
\hline 21 & Kelompok Kompas Gramedia & Publisher & Private \\
\hline 22 & PT Microsoft Indonesia & Information Technology & Private \\
\hline 23 & PT Permodalan Nasional Mandiri (Persero) & Financial Institution & SOE \\
\hline 24 & PT Pertamina (Persero) & Oil and Gas & SOE \\
\hline 25 & Perum Peruri & Manufacturing & $\mathrm{SOE}$ \\
\hline 26 & PT (Persero) Angkasa Pura 1 & Services & $\mathrm{SOE}$ \\
\hline
\end{tabular}

for research that analyzes data using SEM (Hair et al., 1998). The general description of respondents that are arranged in the form of tables and piediagrams are as follows:
This chapter is about the statistical analysis of the research data which was obtained using a questionnaire as the main research instrument. The data itself covers 26 organizations, and is comprised of 756 returned and completed 
questionnaires as well as respondents' profiles. The researcher has been granted permission by LM-FEUI to use the data for the purpose of this research. Statistical analysis is conducted as one of the requirements for SHP (Seminar Hasil Penelitian -Research Results Seminar) examination defense. The analysis is done by using Structural Equation

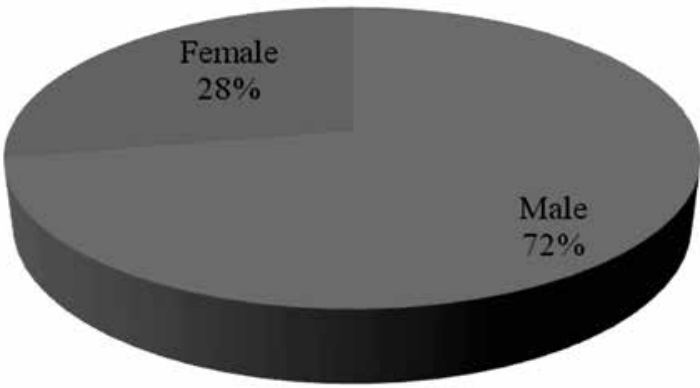

Figure 1. Responden Profile by Gender

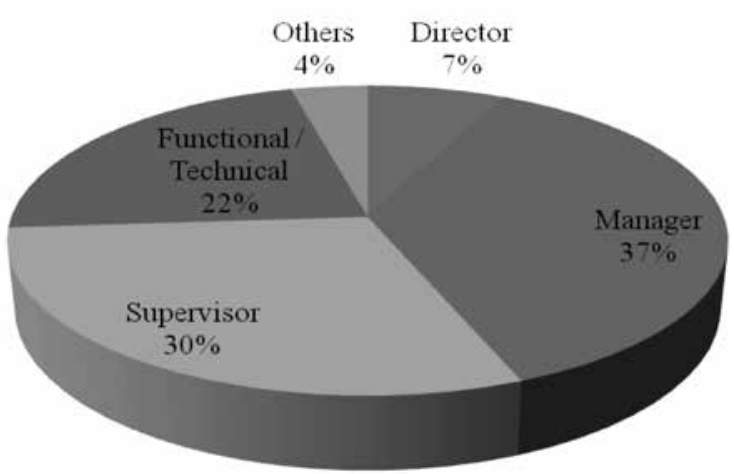

Figure 3. Responden Profile by Position

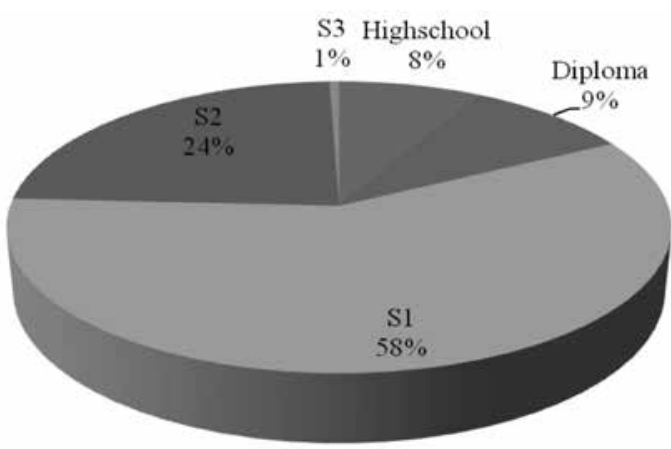

Figure 5. Responden Profile by Educational Background
Modeling (SEM) with Lisrel version 8.8 software, comprised of measurement model analysis, latent variable simplification by measuring Latent Variable Score (LVS), Confirmatory Factor Analysis (CFA) test results, structural model test, and hypothesis test result discussions.

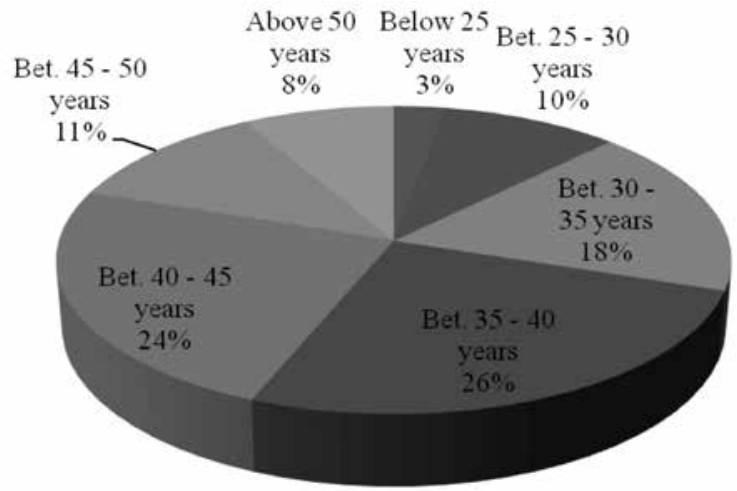

Figure 2. Responden Profile by Age

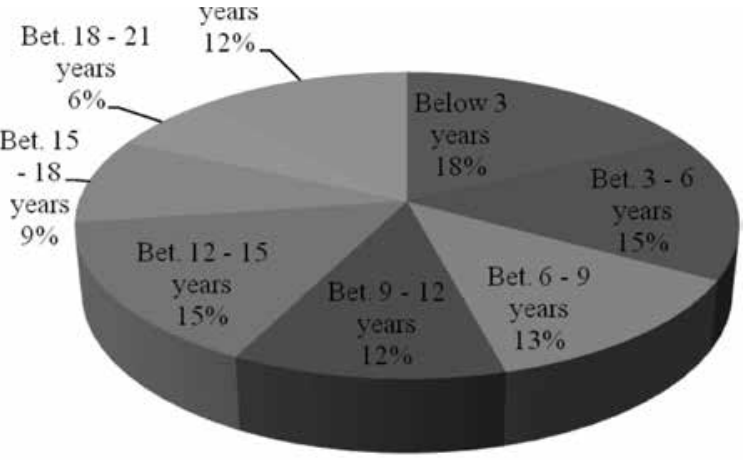

Figure 4. Responden Profile by

Working Experience

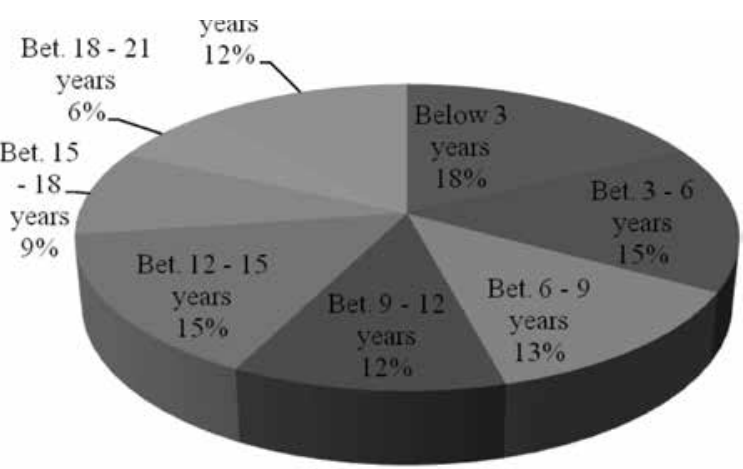

Figure 6. Responden Profile by Working Status 


\section{RESULTS AND DISCUSSIONS}

The matrix below delineates the hypotheses pertinent to the conceptual model above and the findings of the research that has been conducted in order to ascertain their correctness.

\section{Theoretical Contributions of the Research}

There are several past studies on employee engagement, yet the majority of those are constructed by limited number of antecedents. Hence, in order to specifically contribute to the development of talent management and employee engagement theories, this study makes several contributions as in table 3 .

\section{Managerial Implications of the Research}

Furtherrmore, this research generates some managerial implications, and its summary is as in table 4 .

\section{Future Research Directions}

Along with very recent literature, the findings and limitations of this empirical study generate some directions for future research. For instance, due to continuing developments in employee engagement theory, there is an urgent need to find key drivers and predictors of engagement based on a firm and valid theoretical model to enable us to "understand better the reasons why the drivers relate to engagement" as Albrecht (2010, p. 10) puts it.

Table 2. Matrix of Hypotheses and the findings of the research

\begin{tabular}{|c|c|c|}
\hline & Hypotheses & Findings \\
\hline $\mathrm{H} 1$ & $\begin{array}{l}\text { Talent management practices positively influence employee } \\
\text { engagement }\end{array}$ & Hypotheses is accepted \\
\hline $\mathrm{H} 2$ & $\begin{array}{l}\text { Perceived organizational culture positively influences } \\
\text { employee engagement }\end{array}$ & Hypotheses is accepted \\
\hline H3 & $\begin{array}{l}\text { Perceived organizational support (POS) positively influences } \\
\text { employee engagement }\end{array}$ & Hypotheses is not accepted \\
\hline $\mathrm{H} 4$ & $\begin{array}{l}\text { Transformational leadership behavior positively influence } \\
\text { talent management practices }\end{array}$ & Hypotheses is accepted \\
\hline H5 & $\begin{array}{l}\text { Transactional leadership behavior positively influences talent } \\
\text { management practices }\end{array}$ & Hypotheses is not accepted \\
\hline H6 & $\begin{array}{l}\text { Interaction between Transformational and Transactional } \\
\text { leadership behaviors positively influences talent management } \\
\text { practices }\end{array}$ & Hypotheses is accepted \\
\hline $\mathrm{H} 7$ & $\begin{array}{l}\text { Transformational leadership behavior positively influences } \\
\text { perceived organizational culture }\end{array}$ & Hypotheses is accepted \\
\hline $\mathrm{H} 8$ & $\begin{array}{l}\text { Transactional leadership behavior positively influences } \\
\text { perceived organizational culture }\end{array}$ & Hypotheses is not accepted \\
\hline H9 & $\begin{array}{l}\text { Interaction between Transformational and Transactional } \\
\text { leadership behaviors positively influences perceived } \\
\text { organizational culture }\end{array}$ & Hypotheses is accepted \\
\hline $\mathrm{H} 10$ & $\begin{array}{l}\text { Transformational leadership behavior positively influences } \\
\text { perceived organizational support (POS) }\end{array}$ & Hypotheses is accepted \\
\hline $\mathrm{H} 11$ & $\begin{array}{l}\text { Transactional leadership behavior positively influences } \\
\text { perceived organizational support (POS) }\end{array}$ & Hypotheses is not accepted \\
\hline $\mathrm{H} 12$ & $\begin{array}{l}\text { Interaction between Transformational and Transactional } \\
\text { leadership behaviors positively influences perceived } \\
\text { organizational support (POS) }\end{array}$ & Hypotheses is accepted \\
\hline
\end{tabular}


Table 3. Theoretical Contribution

\begin{tabular}{|c|c|c|c|}
\hline \multirow[t]{2}{*}{ No } & \multicolumn{2}{|c|}{ Related Concept(s) } & \multirow[t]{2}{*}{ Theoretical Contributions } \\
\hline & Theories \#1 & Theories \#2 & \\
\hline 1 & Leadership behavior & $\begin{array}{l}\text { Employee } \\
\text { engagement }\end{array}$ & $\begin{array}{l}\text { - This study affirms that employee engagement starts } \\
\text { with leadership. } \\
\text { - To increase employee engagement, leaders create } \\
\text { meaning, a culture for engagement, develop and } \\
\text { implement talent management practices. }\end{array}$ \\
\hline 2 & $\begin{array}{l}\text { Talent management } \\
\text { practices }\end{array}$ & Social exchange & $\begin{array}{l}\text { - Talent management practices may be considered } \\
\text { as social exchange, not only transactional in nature. } \\
\text { - Employees feel more obliged to repay the } \\
\text { organization when they are receive more training } \\
\text { and when their contributions are recognized. }\end{array}$ \\
\hline 3 & $\begin{array}{l}\text { Organizational } \\
\text { culture }\end{array}$ & $\begin{array}{l}\text { Employee } \\
\text { engagement }\end{array}$ & $\begin{array}{l}\text { - This empirical research affirms previous research } \\
\text { findings that organizational culture influences } \\
\text { employee engagement. } \\
\text { - Talent management practices alone are not } \\
\text { sufficient to engage talented employees. }\end{array}$ \\
\hline 4 & POS & $\begin{array}{l}\text { Employee } \\
\text { engagement }\end{array}$ & $\begin{array}{l}\text { - One finding is that POS does not significantly } \\
\text { influence employee engagement. However, a } \\
\text { competing theory (Levinson, 1965) says that } \\
\text { POS may influence organizational culture and } \\
\text { other organizational activities. In other words, } \\
\text { POS indirectly influences employee engagement } \\
\text { through mediating variables such as organizational } \\
\text { culture. }\end{array}$ \\
\hline 5 & $\begin{array}{l}\text { Transformational, } \\
\text { transactional and } \\
\text { interaction between } \\
\text { transformational } \\
\text { and transactional } \\
\text { leadership behaviors }\end{array}$ & $\begin{array}{l}\text { Talent } \\
\text { management } \\
\text { practices, } \\
\text { organizational } \\
\text { culture and POS }\end{array}$ & $\begin{array}{l}\text { - One finding is that transactional leadership } \\
\text { behavior is necessary but, by itself, does not } \\
\text { significantly influence talent management } \\
\text { practices, organizational culture and POS. It has } \\
\text { to be combined with transformational leadership } \\
\text { behavior to influence the three mediating variables. } \\
\text { - This finding contributes to the theory development } \\
\text { of interaction or combination of transformational } \\
\text { and transactional leadership behaviors. }\end{array}$ \\
\hline
\end{tabular}

6 Single research model of leadershipdriven employee engagement as a new theoretical framework
- In this empirical research, a particular theoretical contribution is expected by concurrently incorporating key variables (i.e. leadership, talent management practices, organizational culture) as antecedents of employee engagement in a single research model as it may be one of the first few researches to do so.

- This research construct allows for relative and comparative investigation of key variables in predicting employee engagement as an outcome variable.

7 Level of employee engagement as a

- This empirical research integrates theories of strategic human resources and strategic management to suggest that the level of employee engagement can be an organization's performance indicator, as well, it can measure a company's source of sustainable competitive advantage. 
Table 4. Managerial Implications and Summary

\begin{tabular}{|c|c|c|}
\hline No & Variables & Implications \\
\hline 1 & Leadership behavior & $\begin{array}{l}\text { - Organizations should develop more transformational leaders. } \\
\text { combactional leadership behavior is necessary but leaders should } \\
\text { leadership effectiveness. }\end{array}$ \\
\hline 2 & $\begin{array}{l}\text { Talent management } \\
\text { practices }\end{array}$ & $\begin{array}{l}\text { Leaders should initiate and implement talent management } \\
\text { practices in order to: } \\
\text { - understand what key factors attract high potential. } \\
\text { - develop structured and robust learning and development } \\
\text { programs to build organizational competence / capability. } \\
\text { - develop talent pools to ensure smooth succession. }\end{array}$ \\
\hline 3 & Organizational culture & $\begin{array}{l}\text { - To influence employee engagement positively, leaders must } \\
\text { ensure alignment between organizational and employee vision, } \\
\text { mission, values as well as goals. }\end{array}$ \\
\hline 4 & $\begin{array}{l}\text { Employee } \\
\text { engagement }\end{array}$ & $\begin{array}{l}\text { - Leaders must specifically assign and hold responsible every } \\
\text { manager to their score of employee engagement as a manager's } \\
\text { key performance indicators (KPIs). } \\
\text { - Aggregate employee engagement score from all departments } \\
\text { reflects a surrogate variable of organizational performance. }\end{array}$ \\
\hline
\end{tabular}

In this direction, it may be fruitful to look at theories linked to employee engagement such as conservation of resources or COR Theory (Hobfoll, 1989 in Albrecht, 2010), self determination or SDT Theory (Deci \& Ryan, 1985 in Albrecht, 2010), social exchange or SET theory (Blau, 1964), social identity or SIT Theory (Tajfel, 1974 in Albrecht, 2010), Role Theory (Kahn, 1990), Broaden-And-Build Theory of positive emotion (Fredrickson, 2001 in Albrecht, 2010), job characteristics or JCT Theory (Hackman \& Oldham, 1980 in Albrecht, 2010) and the jobdemands-resources or JD-R Model (Bakker \& Demerouti, 2007). Practitioners are desperate for solid knowledge for specific buttons to press that will enable them to create, increases, and sustain various levels of employee engagement. They require practical predictors and solid drivers of employee engagement that can be applied to any organizational context and supported by more integrated theoretical foundations (Albrectht, 2010), particularly those which can be tested for viability and accurate results.

\section{CONCLUSION}

The findings have indicated that leadership behaviors are very important in predicting the employees' level of engagement. Leadershipdriven talent management practices engages high-potential talent which, in turn assures organizational success and performance. Leaders must initiate and activate talent management practices, organizational culture and perceived organizational supports (POS) as the wheels of social exchange. Talent management practices and organizational culture are mediating variables of leadership behavior; all together, they influence employee engagement, although in this study, it was found that the influence of POS on employee engagement was not significant.

To drive the two intangible organizational factors of talent management practices and organizational culture to engage employees, it is vital that leaders display transformational leadership behavior. Although transactional leadership behavior is necessary to drive these two mediating variables, it has to be combined with transformational leadership behavior for maximum effect and influence. 
Implementing talent management practices significantly influences employee engagement. Employees, particularly talented ones, appreciate organizations that further develop their capabilities, measure their performance objectively, and offer job promotions and retention plans. This cause-and-effect relationship suggests that talent management practices can be viewed from a social exchange perspective.

One key leadership responsibility is to develop an effective organizational culture (e.g. Boal \& Hooijberg, 2001; Block, 2003; Buble \& Pavic, 2007; Yukl, 2008) aligned with the organization's business strategies and with employee needs. Leaders must align organizational culture as closely as possible with individual employee values, beliefs and principles; such degree of alignment is directly proportional to the level of employee engagement (Macey et al., 2009; Wildermuth \& Pauken, 2008a).

Research in the fields of talent management and employee engagement continues in the quest to build solid, systematic, and integrated approaches towards robust theoretical concepts for talent management and employee engagement. Researchers, consultants and practitioners should integrate efforts to accelerate the improvement of knowledge gained through the continuous development of theories and practices in talent management and employee engagement.

\section{REFEREN CES}

Appelbaum, S., Bartolomucci, N., Beaumier, E. Boulanger, J., Corrigan, R., Doré, I., Girard, C., \& Serroni, C. (2004). Organizational citizenship behavior: a study of culture, leadership and trust. Management Decision, 13-40.

Aselage, J., \& Eisenberger, R. (2003). Perceived organizational support and psychological contracts: A theoretical integration. Journal of Organizational Behavior,24(5),491.

Ashton, C., \& Morton, L. (2005). Managing talent for competitive advantage: Taking a systemic approach to talent management. Strategic HR Review, 4(5), 28-31

Barlett, C. A., \& Ghoshal, S. (2002). Building competitive advantage through people. MIT Sloan Management Review, 34-41.

Barney, JB. (1986). Organizational culture: can it be a source of sustained competitive advantage? Academy of Management Review, 11 (3), 656-665

Bass, B. M. (1985). Leadership and performance beyond expectations. New York: Free Press.

Bass, B. M. (1990b). Stogdill's handbook of leadership: A survey of theory and research. New York: Free Press.

Bass, B. M., Avolio, B., \& Goodheim,L. (1987). Biography and the assessment of transformational leadership at the world-class level. Journal of Management, 13 (1), 7-19.

Berger, L. A. \& Berger, D. R. (2004). The talent management handbook: creating organizational excellence by identifying, developing, and promoting your best people. New York, NY: McGraw-Hill.

Bhal, K. T. (2006). LMX-citizenship behavior relationship: Justice as a mediator. Leadership \& Organization Development Journal, 27(2), 106-117.

Blau, P. (1964). Exchange and power in social life. New York, NY: Wiley.

Block, L. (2003). The leadership-culture connection: an exploratory investigation. Leadership \& Organization Development Journal, 24(6), 318-334.

Boal, K. B., \& Hooijberg, R.(2001). Strategic leadership research: Moving on. Leadership Quarterly, 11(4). 515-549.

Boardman, A. E., \& Vining, A. R. (1989). Ownership and performance in competitive environments: A comparison of the performance of private, mixed, and state-owned enterprises. Journal of Law and Economics, 32(1), 1-33.

Buble, M., \& Pavic, I. (2007). Interdependence between organizational culture and leadership styles: The Croatian case. The Business Review, 7(1), 143-150. 
Buckingham, M. \& Coffman, C. (2005). First, break all the rules: what the world's greatest managers do differently. London, UK: Simon \& Schuster UK Ltd.

Burns, J. M. (1978). Leadership. New York, NY: Harper \& Row.

Byrne, Z. S., \& Hochwarter, W. A. (2008). Perceived organizational support and performance Relationships across levels of organizational cynicism. Journal of Managerial Psychology, 23(1), 54-72.

Cameron, K. S. \& Quinn, R. E. (2006). Diagnosing and changing organizational culture: based on competing values framework. San Francisco. CA: Jossey-Bass.

Cappelli, P. (2008a). Promises and challenges of the talent on demand model: Creating a new paradigm. Boston, Massachusetts: Harvard Business Press.

Cascio, W. F. (2003). Managing human resources: Productivity, quality of work life, profits (6th ed.). New York, NY: McGrawHill/Irwin.

Chen, A. (1998). Inertia in reforming china's state-owned enterprises: The case of chongqing. World Development, 26(3), 479-495.

Colan, L. J. (2009). Engaging the hearts and minds of all your employees. USA: McGraw-Hill.

Cole, M. S., Schaninger Jr., W. S., \& Harris, S. G. (2002). The workplace social exchange network: A multilevel, conceptual examination. Group \& Organization Management, 27(1), 142-167.

Collings, D. G., \& Mellahi, K. (2009). Strategic talent management: A review and research agenda. Human Resource Management Review, 19, 304-313.

Cook, S. (2008). The essential guide to employee engagement: better business performance through staff satisfaction. London, UK: Kogan Page Limited.

Corace, C. J. (2007). Engagement-enrolling the quiet majority. Organizational Development Journal, 25(2), $171-175$.

Croston, D. (2008). Employee engagement: the people's approach to building a business. Sydney. NSW: Moonstone Media.

Denison, D. R. (1990). Corporate culture and organizational effectiveness. USA: John Wiley \& Sons.

Denison, D. R. Haaland, S., \& Goelzer, P. (2003). Corporate culture and organizational effectiveness: Is there a similar pattern around the world? Advances in Global Leadership, 3, 205-227.

Dienesch, R. \& Liden, R. (1986). Leader-member exchange model of leadership: A critique and further development. Academy of Management Review, 11, 618-634.

Eisenberger, R., Fasolo, P., \& Davis-LaMastro, V. (1990). Perceived organizational support and employee diligence, commitment, and innovation. Journal of Applied Psychology, 75, 51-59.

Eisenberger, R., Huntington, R., Hutchinson, S., \& Sowa, D. (1986). Perceived organizational support. Journal Applied Technology, 71(3), 500-507.

Fey, C. F., \& Denison, D. R. (2003). Organizational culture and effectiveness: Can American theory be applied in Russia? Organization Science, 14(6), 686-706.

Fleming, J.H., \& Asplund, J. (2007). Human sigma: managing the employee-customer encounter. New York, NY: Gallup Press. Gouldner, A. W. (1960a). The norm of reciprocity: A preliminary statement. American Sociological Review, 25 (2), $161-178$.

Gouldner, A.W. (1960b). The norm of reciprocity. American Sociological Review, 25, 165-167.

Grant, R. M. (1999). Transforming uncertainty into success: The strategic leadership forum 1999. Strategy \& Leadership, 27(4/5), 31-36

Harter, J. K., Schmidt, F. L., \& Hayes, T. L. (2002). Business-unit-level relationship between employee satisfaction, employee engagement, and business outcomes: A meta-analysis. Journal of applied Psychology, 87(2), 268-279.

Hay Group. Employee engagement: Highly engaged workers create better financial performance. Retrieved August 19, 2009 from http://www.haygroup.com/ww/services/index.aspx?

Heger, B. K. (2007). Linking the employment value proposition (EVP) to employee engagement and business outcomes: Preliminary findings form a linkage research pilot study. Organization Development Journal, 25(2), 121 -233.

Hickman, G.R. (1998). Leadership and social imperative of organization in the $21^{\text {st }}$ century. In G.R. Hickman (Ed.). Leading organizations: Perspectives for a new era (pp. 559-571). Thousand Oaks, CA: Sage

Hitt, M. A., Haynes, K. T., \& Serpa, R. (2010). Strategic leadership for $21^{\text {st }}$ century. Business Horizon, $836,1-8$.

Hollander, E. P. (1986). On the central role of leadership processes. International Review of Applied Psychology, 35, 39-52.

House, R.J., \& Aditya, R. (1997). The social scientific study of leadership: Qua vadis? Journal of Management, 23, $409-474$.

Hughes, J. C., \& Rog, E. (2008). Talent management: A strategy for improving employee recruitment, retention and engagement within hospitality organizations. International Journal of Contemporary Hospitality Management, 20(7), 743-757.

Hunt, S.D. (1991). Modern marketing theory: Critical issues in the philosophy marketing science. Cincinnati: South-Western.

Ireland, R.D., \& Hitt, M.A. (1999). Achieving and maintaining strategic competitiveness in the $21^{\text {st }}$ century: The role of strategic leadership. Academy of Management Executive, 13, 43-57. 
Kahn, W. A. (1990). Psychological conditions of personal engagement and disengagement at work. Academy of Management Journal, 33(4), 629-724.

Kaplan, R. S. \& Norton, D. P. (1996). The balanced scorecard: translating strategy into action. Boston, MA: Harvard Business School Press.

Keesing, R. M. (1974). Theories of Culture. Annual Review of Anthropology, 3, 73-97. (doi: 10.1146/annurev.an.03.100174.000445)

Kiggundu, M. N. (1994). Managing research institutions in developing countries: Test of a model. Public Administration Development, 14(2), 201-222.

Konrad, A. M. (2006). Engaging employees through high involvement work practices. Ivey Business Journal, April-March, 1-6.

Kuhnert, K. W., \& Lewis, P. (1987). Transactional and transformational leadership: a constructive/developmental analysis. The Academy of Management Review, 12(4), 648-657.

Lacy, P., Arnott, J., \& Lowitt, E. (2009). The challenge of integrating sustainability into talent and organization strategies: investing in the knowledge, skills and attitudes to achieve high performance. Corporate Governance, 9(4), 484-494.

Lawler III, E. E. (2008). Talent: making people your competitive advantage. San Francisco, CA: Jossey-Bass.

Levinson, H. (1965). The relationship between man and organization. Administrative Science Quarterly, 9(4), 370 - 390.

Lewis, R. E., \& Heckman, R. J. (2006). Talent management: A critical review. Human Resource Management Review, 16, 139154.

Luthans, F., \& Peterson, S. J. (2002). Employee engagement and manager self-efficacy: Implications for managerial effectiveness and development. The Journal of Management Development, 21(5), 376-387.

Macey, W. H., \& Schneider, B. (2008). The meaning of employee engagement. Industrial and Organizational Psychology, 1, 3-30.

Macey, W. H., Schneider, B., Barbera, K. M., \& Young, S. A. (2009). Employee engagement: Tools for analysis, practice, and competitive advantage.

May, D. R., Gilson, R. L., \& Harter, L. M. (2004). The psychological conditions of meaningfulness, safety and availability an the engagement of the human spirit at work. Journal of Occupational an Organizational Psychology, 77, 11-37.

McGregor, E. B., Jr. (1988). The public sector human resource puzzle: Strategic management of a strategic resource. Public Administration Review, 48(6), 941-950.

Michaels, E., Handfield-Jones, H., \& Axelrod, B. (2001). The war for talent. Boston, MA: Harvard Business School Press.

Nguyen, T. V. (2003). Managing change in vietnamese state-owned enterprises: What is the best strategy? Human Resource Management Review, 13, 423-428.

Obloj, K., \& Thomas, H. (1996). Breaking away from the past: Strategies of successful polish firm. European Management Journal, 14(5), 467-476.

Ormanidhi, A., \& Stringa, O. (2008). Porter's model of generic competitive strategies: An insightful and convenient approach to firms' analysis. Business Economics, 55-64.

Peteraf, M. A., \& Barney, J. B. (2003). Unraveling the resource-based tangled. Managerial and Decision Economics, 24(4), 309-323.

Pfeffer, J. (1995). Producing sustainable competitive advantage through the effective management of people. (1994). Academy of Management Executive, 9(1), 55-71.

Pfeffer, J. (2001). Fighting the war for talent is hazardous to your organization's health. Organizational Dynamics, 29(4), 248259.

Relationship between organizational commitment and organizational citizenship: Research quarterly for exercise and sport. Academic Research Library, 76(1), A48.

Rich, B. L., Lepine, J. A., \& Crawford, E. A. (2010). Job engagement: Antecedents and effects on job performance. Academy of Management Journal, 53(3), 617-635.

Saks, A. M. (2006). Antecedents and consequences of employee engagement. Journal of Managerial Psychology, 21 (7), 600619.

Saks, A. M. (2008). The meaning and bleeding of employee engagement: How muddy is the water? Industrial and Organizational Psychology, 1, 40-43.

Schaufeli, W. B., \& Bakker, A. B. (2004). Job demands, job resources, and their relationship with burnout and engagement: A multi-sample study. Journal of Organizational Behavior, 25, 293-315.

Schein, E. H. (1990). Organizational culture. American Psychologist, 45(2), 109-119.

Schein, E. H. (1996). Culture: The missing concept in organization studies. Administrative Science Quarterly, 41(2), 229-240.

Schiemann, W.A. (2009). Reinventing talent management: How to maximize performance in the new marketplace. Hoboken, New Jersey: John Wiley \& Sons, Inc.

Selznick, P. (1984). Leadership in administration: A sociological interpretation. Berkeley: University of California Press (originally published 1957). 
Shore, L. M. F., \& Tetrick, L. E. (1991). A construct validity study of the survey of perceived organizational support. Journal of Applied Psychology, 76(5), 637-643.

Shuck, M. B. (2010). Employee engagement: An examination of antecedent and outcome variables. USA: Florida International University.

Sikula Sr., A. (2001). The five biggest HRM lies. Public Personnel Management, 30(3), 419-428.

Spencer, L. M. \& Spencer, S. M. (1993). Competence at work: models for superior performance. USA, John Wiley \& Sons, Inc. Towers Perrin. (2003). Working today: understanding what drives employee engagement. The Towers Perrin Talent Report, 1-44. Viverita \& Ariff, M. (2008). On productivity performance gains of Indonesian firms. Managerial Finance, 34(9), 644-659.

Wang, X. (2008). Analyzing work attitudes of chinese employees: A comparison between state-owned and privately-owned enterprises in china. Chinese Management Studies, 2(3), 215-228.

Wat, D., \& Shaffer, M. A. (2005). Equity and relationship quality influences on organizational citizenship behaviors: The mediating role of the trust in the supervisor and empowerment. Personnel Review, 34(4), 406.

Watson Wyatt. (2007, November 20). Watson Wyatt reveals research finding connection between employee engagement and business success. Watson Wyatt World Wide. 20 November 2007. Retrieved August 19, 2009 from http://www. watsonwyatt.com/asia-pasific/news/press.asp

Wayne, S. J., Shore, L. M., \& Liden, R. C. (1997). Perceived organizational support and leader-member exchange: a social exchange perspective. The Academy of Management Journal, 40(1), 82-111.

Wayne, S. J., Shore, L. M., Bommer, W. H., \& Tetrick, L. E. (2002). The role of fair treatment and reward in perceptions of organizational support and leader-member exchange. Journal of Applied Psychology, 87(3), 590-598.

Wielemaker, M., \& Flint, D. (2005). Why does HRM need to be strategic? A consideration of attempts to link human resources \& strategy. The Business Review, Cambridge, 3(2), 259-264.

Wildermuth, C. M. S., \& Pauken, P. D. (2008a). A perfect match: decoding employee engagement - Part I: Engaging cultures and leaders. Industrial and Commercial Training, 40(3), 122-128.

Yukl, G. (2002). Leadership in organizations (5th ed). New Jersey: Prentice Hall.

Yukl, G. (2006). Leadership in organization (6th ed.). New Jersey: Prentice Hall.

Yukl, G. (2008). How leaders influence organizational effectiveness. The Leadership Quarterly, 19, 708-722. 